\title{
ANALISIS PERAN PEMANGKU KEPENTINGAN PADA PENERAPAN TATA KELOLA KORPORAT USAHA MIKRO KECIL DAN MENENGAH KOTA SURABAYA
}

\author{
Bernadetta Diana Nugraheni* \\ Cyrillius Martono \\ Universitas Katolik Widya Mandala Surabaya, Jalan Dinoyo 42-44, Surabaya \\ bernadetta@ukwms.ac.id
}

\author{
A R T I C L E I N F O \\ Article history: \\ Received September 14, 2018 \\ Revised November 5, 2018 \\ Accepted November 14, 2018
}

Key words:

Stakeholders, Transparency, Accountability, Responsibility, Independence fairness

\begin{abstract}
A B S T R A C T
In general, the implementation of MSMEs has not implemented good organizational governance, especially in the principles of transparency and accountability. This study aims to examine and analyze the roles and responsibilities of stakeholders, especially the owners and managers of MSMEs in implementing organizational governance, in the city of Surabaya. This research is an exploratory study with survey design. Population and sample of this study took UMKM in the city of Surabaya. The results of this study can be concluded that the principle of transparency as a whole has not been realized properly. On the principle of accountability related to responsibility in compiling reports on organizational activities and the implementation of monitoring and evaluation of the work of employees can be said to be quite good. While the principle of responsibility as a whole is said not to materialize. On the principle of independence, the authority to coordinate daily operational tasks does not materialize. And on the principle of reasonableness indicates that there are still management interventions from the owner / family.
\end{abstract}

\begin{abstract}
A B S T R A K
Secara umum, implementasi atas UMKM belum menerapkan tata kelola organisasi yang baik, terutama dalam prinsip transparansi dan akuntabilitas. Penelitian ini bertujuan untuk menguji dan menganalisis peran dan tanggung jawab pemangku kepentingan, terutama pemilik dan manajer UMKM dalam menerapkan tata kelola organisasi, di kota Surabaya. Penelitian ini adalah penelitian eksploratif dengan desain survei. Populasi dan sampel penelitian ini adalah UMKM di kota Surabaya. Dari hasil penelitian ini dapat disimpulkan bahwa prinsip transparansi secara keseluruhan belum terealisasi dengan baik. Pada prinsip pertanggungjawaban terkait dengan tanggung jawab dalam menyusun laporan kegiatan organisasi dan pelaksanaan pemantauan dan evaluasi kerja karyawan dapat dikatakan cukup baik. Sedangkan prinsip tanggung jawab secara keseluruhan dikatakan tidak terwujud. Pada prinsip independensi, wewenang untuk mengoordinasikan tugas operasional sehari-hari tidak terwujud. Dan pada prinsip kewajaran menunjukkan bahwa masih ada intervensi manajemen dari pemilik/keluarga.
\end{abstract}

\section{PENDAHULUAN}

Bukan hal yang asing bahwa sektor usaha mikro kecil menengah (UMKM) merupakan salah satu motor penggerak perekonomian Indonesia dan menjadi fokus pemerintahan Presiden Joko Widodo (Jokowi), (kompas.com). Jumlah pelaku UMKM di Indonesia dilaporkan mencapai 49 juta dan diprediksi menyerap lebih dari 107 juta tenaga kerja. Kontribusi sektor UMKM terhadap produk domestik bruto (PDB) pun semakin meningkat dalam lima tahun terakhir di mana Kementerian Koperasi dan Usaha Kecil Menengah mencatat lonjakan dari 57,84 persen menjadi 60,34 persen di tahun 2016.Di antara UMKM, industri ekonomi kreatif juga tercatat berkembang positif dengan pertumbuhan 5,6 persen antara 2010-2013. Industri ini menyumbang 7,1 persen terhadap PDB dan berhasil menyerap sekitar 12 juta tenaga kerja, menjadikannya salah satu ranah andalan untuk mendorong peningkatan pendapatan masyarakat serta berperan strategis dalam memerangi pengangguran dan kemiskinan, (kompas.com). Dari uraian diatas perlu secara terus menerus UMKM mendapat perhatian yang serius. Masalah klasik 
yang dihadapi UMKM adalah masalah finansial dan nonfinansial (organisasi manajemen),seperti diungkapkan (Niode, 2009), masalah finansial yang biasa dihadapi adalah (1) Kurangnya kesesuaian (terjadinya mismatch) antara dana yang tersedia yang dapat diakses oleh UMKM. (2) Tidak adanya pendekatan yang sistematis dalam pendanaan UMKM (3) Biaya transaksi yang tinggi, yang disebabkan oleh prosedur kredit yang cukup rumit sehingga menyita banyak waktu sementara jumlah kredit yang dikucurkan kecil (4) Kurangnya akses kesumber dana yang formal, baik yang disebabkan oleh ketiadaan bank dipelosok maupun tidak tersedianya informasi yang memadai (5) Bunga kredit untuk investasi maupun modal kerja yang cukup tinggi (6) Banyaknya UMKM yang belum bankable, baik disebabkan belum adanya manajemen keuangan yang transparan maupun $\mathrm{ku}-$ rangnya kemampuan manajerial dan finansial, sedangkan yang termasuk dalam masalah organisasi manajemen (non finansial) diantaranya menurut (Niode, 2009) adalah (1) Kurangnya pengetahuan atas teknologi produksidan quality control yang disebabkan minimnya kesempatan untuk mengikuti perkembangan teknologi serta kurangnya pendidikan dan pelatihan. (2) Kurangnya pengetahuan akan pemasaran, yang disebabkan oleh terbatasnya informasi yang dapat dijangkau oleh UMKM mengenai pasar, selain karena keterbatasan kemampuan UMKM untuk menyediakan produk/ jasa yang sesuai dengan keinginan pasar. (3) Keterbatasan sumber daya manusia (SDM) serta kurangnya sumber daya untuk mengembangkan SDM. (4) Kurangnya pemahaman mengenai keuangan dan akuntansi.

Pelaksanaan dalam pengelolaan organisasi non finansial terutama masalah pada kepedulian pemilik maupun eksekutif terhadap pelaksanaan operasional UMKM sangat besar pengaruhnya. Roida, Sunarjanto dan Jayaprana (2010) meneliti apakah suatu bentuk atau struktur kepemilikan memiliki hubungan terhadap keterlibatan UMKM dalam internasionalisasi. Hasil penelitian tersebut menyimpulkan bahwa struktur dan bentuk kepemilikan keluarga tidak dapat memberikan penjelasan mengenai pengaruh keterlibatan UMKM dalam pengambilan dalam pengambilan keputusan internasionalisasi.

Bentuk kepemilikan atau struktur kepemilikan secara umum dapat dikelompokkan menjadi tiga yaitu (1) Kepemilikan keluarga, merupakan bentuk dimana pemilik dan manajer adalah sama, sehingga semua dikerjakan tanpa campur tangan pihak luar. (2) Kepemilikan korpo- rasi, adalah kepemilikan yang beranggotakan beberapa orang, dan untuk pelaksanaan sekaligus kontrol usaha para pemilik ditunjuk seorang manajer. (3) Kepemilikan kombinasi, merupakan gabungan/kombinasi kepemilikan antara keluarga dan sebagian lagi dimiliki oleh korporasi atau disebut juga corporate blockholder.

Penelitian yang dilakukan Nugraheni dan Martono (2017) terhadap UMKM industri produk tekstil di Pekalongan, menyimpulkan bahwa 52\% sampel belum melaksanakan tata kelola korporat yang baik, khususnya untuk prinsip transparansi dan akuntabilitas.Prinsip transparansi menyebutkan bahwa perusahaan harus dapat selalu menyediakan informasi yang material dan relevan kepada para pemangku kepentingan. Sedangkan prinsip akuntabilitas menekankan bahwa perusahaan harus dapat dikelola dengan cara yang sesuai dan terukur, sesuai dengan keinginan perusahaan dan para pemangku kepentingan. Disini terlihat bahwa pemangku kepentingan baik pemerintah maupun masyarakat memiliki peran yang sangat penting untuk kemajuan UMKM sendiri.

Penelitian yang dilakukan oleh Putri dan Bakhtiar (2015) menjelaskan bahwa dalam rangka memperjuangkan keberlanjutan usahanya, para pelaku usaha sangat menyadari pentingnya penyusunan laporan keuangan secara periodik untuk membantu mereka melakukan internal kontrol dan membangun tatakelola organisasi yang baik khususnya dalam hal keuangan. Zhang dan Thiam (2014) yang menilai bagaimana peran stakeholder dalam keikutsertaannya terhadap pelaksanaan prinsip-prinsip tata kelola perusahaan SME (Small and Medium Enterprises) menyatakan bahwa praktik tata kelola yang baik memberikan kontribusi pada peningkatan reputasi SME itu sendiri. Demikian juga organisasi-organisasi SME lebih mengutamakan transparansi dan akuntabilitas keuangannya untuk kepentingan para pemegang saham dan para kreditor. Koech (2016) menghasilkan temuan bahwa karakteristik dari board berkorelasi positif dengan corporate governance khususnya integritas board, prosedur pemilihan board, dan pengawasan. Artinya bahwa perusahaan yang memiliki pemimpin yang berintegritas, pemilihan para pemimpin atau direksi pun melalui prosedur yang benar akan memiliki struktur tata kelola organisasi yang baik pula. Supaya penerapan GCG pada UMKM dapat mencapai kesuksesan, maka penerapannya harus dilakukan dengan melihat dan mempelajari karakteristik jenis usaha, karena UMKM pada ummnya berupa bisnis yang dikendalikan oleh keluarga, sehingga isu-isu 
yang berhubungan dengan permasalahan agensi antara manajer dan pemilik tidak terlalu nampak.

Masalah keagenan (agency problem) sangat mungkin terjadi pada industri UMKM. Dalam perkembangannya, saat ini UMKM pun dijalankan bukan hanya oleh pemilik usaha tetapi juga seseorang yang ditunjuk berperan sebagai agen.Stewardship Theory (Nugraheni dan Martono, 2017) dapat menjelaskan corporate governancedalam paradigma komunitarian (communitarian paradigm), Koech (2016) menyebutkan bahwa teori ini dapat menjelaskan bagaimana organisasi akan lebih mengutamakan kepentingan para pemegang sahamnya.

Palupijati (2013) memaparkan bahwa sebagian besar bisnis kecil menengah merupakan bisnis dimana pemilik juga merangkap sebagai pihak manajemen. Kontrol bisnis akan secara otomatis ada di tangan pemegang saham dan masalah keagenan tidak timbul dalam kondisi bisnis seperti ini. Pernyataan tersebut bertolak belakang dengan penelitian Lane, Astrachan, Keyt dan McMillan (2006) yang menyatakan bahwa banyak bisnis kecil dan menengah tidak menerapkan tata kelola perusahaan dikarenakan tidak adanya masalah keagenan.

Penelitian ini akan fokus kepada kajian dan analisis terhadap peran dan tanggung jawab para pemangku kepentingan khususnya pemilik dan manajer UMKM dalam menerapkan tata kelola korporat pada usaha mereka. Dimana merekalah yang berperan dan bertanggung jawab sebagai pemilik modal, pengambil keputusan, dan pelaksana fungsi kontrol. Sampel penelitian diambil di UMKM kota Surabaya. Pemilihan wilayah di kota Surabaya, bahwa perkembangan UMKM di kota Surabaya dari tahun ke tahun mengalami pertumbuhan pesat hal ini didukung berdasarkan data Dinas Koperasi dan Usaha Mikro Surabaya, jumlah UMKM telah mencapai 4.800 usaha (Widarti, 2017).

Penelitian ini diharapkan memberikan manfaat bagi pemerintah dalam memberikan advise atau pendampingan bagi para pelaku UMKM agar dapat lebih memperhatikan dalam penerapan tata kelola UMKM yang baik. Sedangkan bagi penanggung jawab UMKM adalah dapat menerapkan prinsip-prinsip tata kelola UMKM dengan baik.

\section{KAJIAN LITERATUR DAN PENGEMBANGAN HIPOTESIS \\ Penelitian Terdahulu}

Penelitian yang dilakukan Nugraheni dan Martono (2017) menggunakan sampel industri tekstil di Pekalongan, Jawa Tengah diperoleh hasil bahwa hanya 33\% dan 15\% UMKM di Pekalongan telah melaksanakan prinsip-prinsip tata kelola korporat dengan kriteria berturut-turut baik dan amat baik. Untuk prinsip transparansi dan akuntabilitas masih harus ditingkatkan lagi. Karena kedua prinsip tersebut disimpulkan sangat buruk.

Penelitian yang dilakukan Zhang dan Thiam (2014) menghasilkan temuan bahwa sistem tata kelola korporat yang efektif terhadap SME atas kepatuhan terhadap hukum dan aturan yang berlaku akan menghindarkan perusahaan dari kewajiban berbiaya tinggi, termasuk menghindarkan dari konflik kepentingan, korupsi, fraud, dan insider trading. Sedangkan bagi para manajer SME, akan membantu dalam proses pengambilan keputusan karena struktur, tugas dan tanggung jawab bagi semua yang terlibat dalam organisasi adalah jelas. Dengan tata kelola yang baik juga akan meningkatkan reputasi, efisiensi dan pengembangan perusahaan.

Penelitian oleh Palupijati (2013) menjelaskan aspek pembanding untuk kedua tipe bisnis yang digunakan adalah struktur kepemilikan, struktur bisnis, rewards, returns, dan karir. Hasil penelitian tersebut menunjukkan bahwa masing-masing tipe bisnis sebenarnya sudah melakukan tata kelola perusahaan dalam bisnisnya, tetapi belum terlalu maksimal. Semakin terkonsentrasi kepemilikan dan struktur bisnis, akan cenderung semakin berkurang tingkat transparansi, akuntabilitas, independensi, keadilan dalam perusahaan. Sebaliknya pada perusahaan dengan tingkat konsentrasi kepemilikan dan struktur bisnis yang lebih tersebar, penerapan aspek tersebut meningkat.

\section{Teori Keagenan}

Jensen dan Meckling (1976) menyatakan bahwa hubungan keagenan adalah sebuah kontrak antara manajer (agent) dengan pemilik perusahaan/usaha (principal). Oleh karena itu kontrak yang baik antara pemilik usaha dan manajer adalah kontrak yang mampu menjelaskan hal-hal yang harus dilakukan manajer dalam melakukan pengelolaan dana yang dipercayakan dan pembagian kembalian (return) antara manajer dan pemilik usaha.Hubungan keagenan, seperti hubungan antara pemegang saham dengan manajer, akan efektif selama manajer mengambil keputusan investasi yang konsisten dengan kepentingan pemegang saham. Namun, ketika kepentingan manajer berbeda dengan kepentingan pemilik, maka keputusan yang diambil oleh 
manajer kemungkinan besar adalah mencerminkan preferensi manajer dibandingkan pemilik.

\section{Teori Stewardship}

Raharjo (2007) menyebutkan bahwa teori stewardship mempunyai akar psikologi dan sosiologi yang didesain untuk menjelaskan situasi dimana manajer sebagai steward dan bertindak sesuai kepentingan pemilik (Donaldson dan Davis, 1989, 1991). Dalam teori stewardship manajer akan berperilaku sesuai kepentingan bersama. Ketika kepentingan steward dan pemilik tidak sama, steward akan berusaha bekerja sama daripada menentangnya, karena steward merasa kepentingan bersama dan berperilaku sesuai dengan perilaku pemilik merupakan pertimbangan yang rasional karena steward lebih melihat pada usaha untuk mencapai tujuan organisasi. Asumsi penting dari stewardship adalah manajer meluruskan tujuan sesuai dengan tujuan pemilik. Namun demikian tidak berarti steward tidak mempunyai kebutuhan hidup.

\section{Teori Stakeholder}

Stakeholder merupakan kelompok maupun individu yang dapat mempengaruhi atau dipengaruhi oleh proses pencapaian tujuan organisasi. Untuk menjamin kelangsungan hidup perusahaan, sangat tergantung pada dukungan stakeholder. Semakin powerfull dukungan stakeholder makin besar kemampuan perusahaan dengan lingkungan. Model stakeholder beranggapan bahwa seluruh individu atau kelompok memiliki kepentingan yang sama terhadap perusahaan, Hamdani (2016)

\section{Tata Kelola Korporat}

Nugraheni dan Martono (2015) menjabarkan bahwa dalam kerangka tata kelola ini diatur berbagai hubungan antar stakeholder perusahaan supaya tercapai keseimbangan diantara berbagai kepentingan-kepentingan ekonomi, sosial, individu dan masyarakat dengan mendorong terciptanya sumber daya perusahaan yang dikelola secara efisien dan akuntabilitas pengelolaan perusahaan. Hubungan antara stakeholders yang digunakan untuk menentukan arah dan mengendalikan kinerja suatu perusahaan. Bagaimana perusahaan memonitor dan mengendalikan keputusan dan tindakan manajer puncak, yang disebut governance mechanism, mempengaruhi implementasi strategi. Corporate governance yang efektif menyelaraskan kepentingan manajer dengan pemegang saham, sehingga dapat memberikan keunggulan kom- petitif bagi perusahaan.Sedangkan prinsip-prinsip atau asas-asas umum Good Corporate Governance, yang dijelaskan oleh KNKG (2006), adalah: Keterbukaan informasi (transpararency),Akuntabilitas (accountability), Pertanggungjawaban (responsibility), Kemandirian (independency), dan Kesetaraan dan Kewajaran (fairness).

\section{Mengapa UKM Memerlukan Implementasi Tata Kelola}

Berkaitan dengan elemen good corporate governance, tidak ada 'one size to fit all'. Dalam rangka untuk mengakomodasi nilai dan kebutuhan lokal, Negara tertentu perlu menciptakan standar lokal mereka sendiri.Beberapa ahli tidak sependapat atas dibuatnya standar global untuk tata kelola perusahaan. Iu dan Batten (2001) menawarkan sebuah pandangan, walaupun cara bisnis dan perdagangan antar Negara sama belum tentu berarti sama dalam budaya, perbedaan budaya tetap ada. Asian Development Bank (ADB, 1999; 2000) dan World Bank (1999) menyatakan bahwa tidak ada standar tunggal atas model tata kelola yang dapat diterapkan memecahkan masalah perusahaan pada kondisi yang berbedabeda. Dalam pernyataan khususnya, ADB (2000a) menyatakan bahwa "(e)ach country should formulate its own reform plan and implement measures that suit its specific condition". Oleh karena itu, setiap negara dapat memformulasikan sendiri dan mengunakan ukuran yang sesuai dengan kondisi khusus yang ada, termasuk memformulasi model GCG yang cocok dengan kebutuhan UMKM.

Ada 2 (dua) pandangan yang berimbang dalam menentukan perlu atau tidaknya pedoman khusus GCG untuk UMKM (Abor dan Adjasi, 2007). Pertama, pandangan yang menjelaskan tidak perlunya GCG pada UMKM karena masalah keagenan tidak ada pada skala UMKM, hal ini karena skala usaha ini hanya terdiri dari pemilik dan beberapa karyawan sehingga mekanisme pemilik-manajer meniadakan masalah keagenan yang biasanya ada pada perusahaan besar. Kedua, ada perhatian global atas penerapan GCG pada UMKM (OECD, 2006). Panduan untuk perusahaan terbuka seharusnya dapat juga digunakan oleh UMKM, bukan pada aspek kekomplekannya, tetapi pada penerapan prinsip-prinsip untuk menerapkan sebuah sistem tata kelola yang efektif.Manfaat dari implemetasi tata kelola pada UMKM adalah mereka para wirausahawan yang tumbuh dari UMKM dan menjadi usaha besar. UMKM membutuhkan tambahan sumber daya (seperti: keuangan, aset dan teknologi) untuk tumbuh, penerapan prinsip-prinsip GCG akan 
meningkatkan status bankable dan investable perusahaan tersebut. Hal ini juga sejalan dengan adanya upaya pasar modal memberi peluang UKM untuk go public (BAPEPAM-LK, 2011) pada kelompok papan pengembangan (development board), sebelum layak masuk dalam papan utama.

\section{Pelaksanaan Tata Kelola Pada UMKM}

LPPI (2015) yang bekerja sama dengan Bank Indonesia menjabarkan bahwa karakteristik UMKM merupakan sifat atau kondisi faktual yang melekat pada aktifitas usaha maupun perilaku pengusaha yang bersangkutan dalam menjalankan bisnisnya. Karakteristik ini yang menjadi ciri pembeda antar pelaku usaha sesuai dengan skala usahanya. Menurut Bank Dunia, UMKM dapat dikelompokkan dalam tiga jenis, yaitu: 1. Usaha Mikro (jumlah karyawan 10 orang); 2. Usaha Kecil (jumlah karyawan 30 orang); dan 3. Usaha Menengah (jumlah karyawan hingga 300 orang).

Dalam perspektif usaha, UMKM diklasifikasikan dalam empat kelompok, yaitu: (1) UMKM sektor informal, contohnya pedagang kaki lima. (2) UMKM Mikro adalah para UMKM dengan kemampuan sifat pengrajin namun kurang memiliki jiwa kewirausahaan untuk mengembangkan usahanya. (3) Usaha Kecil Dinamis adalah kelompok UMKM yang mampu berwirausaha dengan menjalin kerjasama (menerima pekerjaan sub kontrak) dan ekspor. (4) Fast Moving Enterprise adalah UMKM yang mempunyai kewirausahaan yang cakap dan telah siap bertransformasi menjadi usaha besar.

Di Indonesia, Undang-Undang yang mengatur tentang Usaha Mikro, Kecil, dan Menengah (UMKM) adalah Undang-Undang Nomor 20 Tahun 2008. Dalam undang-undang tersebut UMKM dijelaskan sebagai: "Sebuah perusahaan yang digolongkan sebagai UMKM adalah perusahaan kecil yang dimiliki dan dikelola oleh seseorang atau dimiliki oleh sekelompok kecil orang dengan jumlah kekayaan dan pendapatan tertentu."

Tabel 1. Kriteria UMKM dan Usaha Besar berdasarkan aset dan omset

\begin{tabular}{|l|l|l|}
\hline \multirow{2}{*}{$\begin{array}{l}\text { UKURAN } \\
\text { USAHA }\end{array}$} & \multicolumn{1}{|c|}{ ASET } & \multicolumn{1}{|c|}{ OMSET } \\
\cline { 2 - 3 } Usaha & Maksimal Rp50 juta & $\begin{array}{l}\text { Maksimal Rp300 } \\
\text { juta }\end{array}$ \\
\hline Usaha & $>$ Rp50 juta - Rp500 & $\begin{array}{l}\text { > Rp300 juta - Rp2,5 } \\
\text { milyar }\end{array}$ \\
Kecil & juta & $>$ Rp2,5 milyar - \\
\hline $\begin{array}{l}\text { Usaha } \\
\text { Menengah }\end{array}$ & $>$ Rp500 juta - Rp10 & $\begin{array}{l}\text { Rp50 milyar } \\
\text { milyar }\end{array}$ \\
\hline $\begin{array}{l}\text { Usaha } \\
\text { Besar }\end{array}$ & $>$ Rp10 milyar & Rp50 milyar \\
\hline
\end{tabular}

Sumber: LPPI (2015)

\section{Kerangka Berpikir}

Bisnis UMKM saat ini berkembang sangat baik, hal ini perlu disadari oleh para pelaku UMKM untuk lebih dapat mengelola usahanya agar berkinerja dengan baik.Penerapan tata kelola organisasi UMKM perlu disadari oleh pelaku usaha.

Bagaimanakah peran dan tanggung jawab para pemangku kepentingan khususnya pemilik dan manajer UMKM dalam menerapkan tata kelola korporat pada usaha mereka, khususnya pada UMKM di kota Surabaya

\section{METODE PENELITIAN}

Penelitian ini mengadopsi jenis penelitian exploratory research dengan survey design (Creswell, 2009) untuk melakukan penarikan kesimpulan atas opini dari dari sampel partisipan UMKM dari populasi UMKM. Objek penelitian ini adalah pemilik-pengelola atau pengelola (manajer) dari usaha yangmasuk dalam kategori usaha kecil dan menengah (UU 20 Tahun 2008) yang berlokasi di Surabaya. Penelitian ini menggunakan kuesioner terstruktur yang berisi pertanyaan dasar yang dapat digunakan untuk mengukur penerapan tata kelola UMKM. Pertanyaan diambil dari pedoman umum Good Corporate Governance yang diperoleh dari KKNG dan kemudian disesuaikan dengan kondisi dari UMKM setempat.

Populasi dalam penelitian ini adalah keseluruhan UMKM di kota Surabaya. Sedangkan teknik pengambilan sampel dengan kriteria UMKM yang bergerak usaha ekonomi produktif yang dimiliki perorangan maupun badan usaha dengan jumlah 80 responden yang digunakan dalam penelitian.

\section{Prosedur Pengumpulan Data}

Penelitian ini mengembangkan instrumen penelitian berupa kuisioner untuk mengumpulkan data melalui survei. Instrumen penelitiaan dirancang berdasarkan kajian pustaka dan dikembangkan dari pilar good corporate governancepada UMKM.Dalam mengumpulkan data dalam penelitian ini, peneliti akan melakukan direct observation atau pengamatan secara langsung, yaitu yai- 
tu metode pengumpulan data primer dengan memberikan pertanyaan-pertanyaan kepada responden individu (Hartono, 2005). Secara umum kuisioner ini digunakan untuk memperoleh data kuantitatif tentang implementasi mekanisme good corporate governance di UMKM. Selajutnya pengumpulan data melalui respon tertulis dengan kuesioner dan mengklasifikasikannya dalam bentu data ordinal yang merupakan data dalam bentuk kategori

\section{Teknik Analisis Data}

Teknik analisis data yang akan dilakukan adalah mengkategorisasi dengan melakukan pengklasifikasian struktur kepemilikan UMKM. Kemudian dari item-item pertanyaan tersebut akan dilakukan tabulasi dan diambil suatu kesimpulan. Perhitungan atas kuesioner dilakukan dengan menjumlahkan jawaban "Ya" dan kemudian menghitung persentase terhadap jumlah kuesioner dikalikan jumlah pertanyaan dengan cara sebagai berikut:

$$
\text { Persentase }=\frac{\sum \text { Jawaban "YA" }}{\sum \text { Jumlah Kuisioner X Jumlah Pertanyaan }} \times 100 \%
$$

Dari persentase tersebut dikategorikan berdasarkan kriteria penilaian yang berkaitan dengan perwujudan Tata kelola korporat pada usaha UMKM adalah sebagai berikut :

Tabel 2. Kriteria Penilaian Perwujudan Tata Kelola

\begin{tabular}{|c|l|}
\hline Persentase & \multicolumn{1}{|c|}{ Kriteria } \\
\hline $0 \%-25 \%$ & $\begin{array}{l}\text { Tata Kelola Korporat tidak } \\
\text { terwujud }\end{array}$ \\
\hline $25 \% \geq 50 \%$ & $\begin{array}{l}\text { Tata kelola Korporat kurang } \\
\text { terwujud }\end{array}$ \\
\hline $50 \% \geq 75 \%$ & $\begin{array}{l}\text { Tata Kelola Korporat cukup } \\
\text { terwujud }\end{array}$ \\
\hline $75 \% \geq 100 \%$ & $\begin{array}{l}\text { Tata Kelola Korporat sangat } \\
\text { terwujud }\end{array}$ \\
\hline
\end{tabular}

Sumber: (Tadikapury, 2011).

\section{HASIL DAN PEMBAHASAN}

\section{Uji Reliabilitas}

Secara umum kuisioner dalam penelitian ini dipergunakan untuk memperoleh data kuantitatif tentang peranan pemangku kepentingan pada penerapan tata kelola korporat dengan memberikan persepsi atas pertanyaan-pertanyaan persetujuan dengan jawaban Ya (1) dan Tidak (0). Secara analisis kuantitatif menjelaskan bahwa in- trumen dikategorikan valid pada saat Cronbach's alpha tidak kurang dari 0,6 sampai dengan 0,70. Setelah dilakukan beberapa kali analisis ulang terhadap item-item pertanyaan maka diperoleh hasil akhir seperti pada tabel 3. Nilai reliabilitas statistik yang ditunjukkan pada tabel 3 sebagai berikut:

Tabel 3.Hasil Analisis Ulang Reliabilitas

Reliability Statistics

\begin{tabular}{|r|r|}
\hline $\begin{array}{c}\text { Cronbach's Al- } \\
\text { pha }\end{array}$ & N of Items \\
\hline .855 & 12 \\
\hline
\end{tabular}

Item-Total Statistics

\begin{tabular}{|l|r|r|r|r|}
\hline & $\begin{array}{c}\text { Scale } \\
\text { Mean if } \\
\text { Item } \\
\text { Deleted }\end{array}$ & $\begin{array}{c}\text { Scale } \\
\text { Variance } \\
\text { if Item } \\
\text { Deleted }\end{array}$ & $\begin{array}{c}\text { Corrected } \\
\text { Item- } \\
\text { Total Cor- } \\
\text { relation }\end{array}$ & $\begin{array}{c}\text { Cronbach's } \\
\text { Alpha if } \\
\text { Item Delet- } \\
\text { ed }\end{array}$ \\
\hline Pilar1.1 & 2.4125 & 7.385 & .622 & .838 \\
Pilar1.3 & 2.5000 & 7.595 & .652 & .837 \\
Pilar2.1 & 2.4750 & 7.822 & .489 & .847 \\
Pilar2.2 & 2.5375 & 8.201 & .391 & .853 \\
Pilar2.3 & 2.4875 & 7.873 & .482 & .847 \\
Pilar3.1 & 2.5750 & 8.096 & .563 & .845 \\
Pilar3.2 & 2.3375 & 7.416 & .544 & .844 \\
Pilar3.3 & 2.4250 & 7.361 & .648 & .836 \\
Pilar4.2 & 2.3000 & 7.377 & .540 & .844 \\
Pilar4.3 & 2.1750 & 7.463 & .473 & .850 \\
Pilar5.1 & 2.5250 & 8.126 & .410 & .852 \\
Pilar5.2 & 2.4000 & 7.382 & .609 & .838 \\
\hline
\end{tabular}

Berdasarkan tabel 3. bahwa semua item pertanyaan mempunyai nilai Corrected Item-Total Correlation lebih besar dari $r$ tabel $(0,361)$, sehingga semua item pertanyaan tersebut dikatakan valid. Dengan mengeliminasi beberapa pertanyaan maka nilai reliabilitas Cronbach's Alpha menjadi lebih tinggi yaitu: 0,855 .

\section{$\underline{\text { Analisis Deskripsi }}$}

Penelitian dilakukan dengan melakukan pengamatan langsung yaitu data dikumpulkan dengan mengamati langsung ke sumber data dan wawancara kepada 125 UMKM di Surabaya dengan metode convenience sampling. Dari 125 responden sebanyak 80 kuesioner yang memenuhi kriteria. Berikut informasi umum yang diperoleh dari responden : 


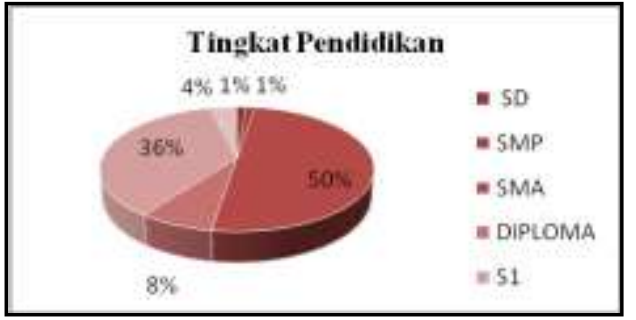

Gambar 1.Tingkat Pendidikan

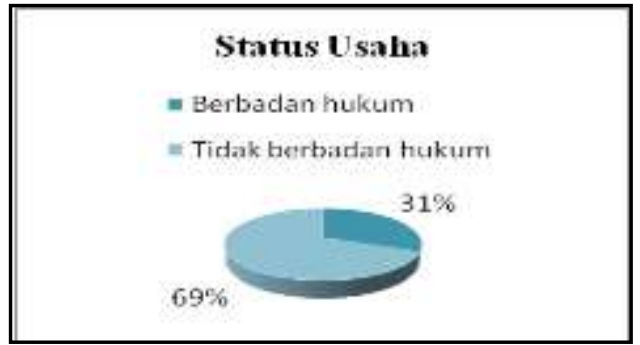

Gambar 2. Status Usaha

Gambar 1 dan gambar 2 menjelaskan bahwa tingkat pendidikan pemilik UMKM yang masih tergolong rendah sangat menetukan dalam penerapan tata kelola korporat pada usaha yang dijalankan, berdasarkan data tersebut $50 \%$ dalam sampel penelitian berpendidikan SMA sehingga untuk menerapkan tata kelola korporat terutama penggunaan informasi akuntansi masih sangat terbatas. Pendidikan manajer yang cukup dan sesuai untuk dapat menggunakan informasi akuntansi tentunya sangat penting agar dapat menerapkan prinsip tata kelola dengan baik pada UMKM. Terkait dengan hal tersebut adalah dari gambar 2 yang menunjukkan bahwa UMKM di surabaya sebagian besar masih belum berbadan hukum yaitu sebesar 69\% (55 responden), hal tersebut berkaitan bahwa sebagian besar responden adalah sebagai badan usaha perseorangan dan hanya $25 \%$ badan usaha mempunyai status badan hukum.

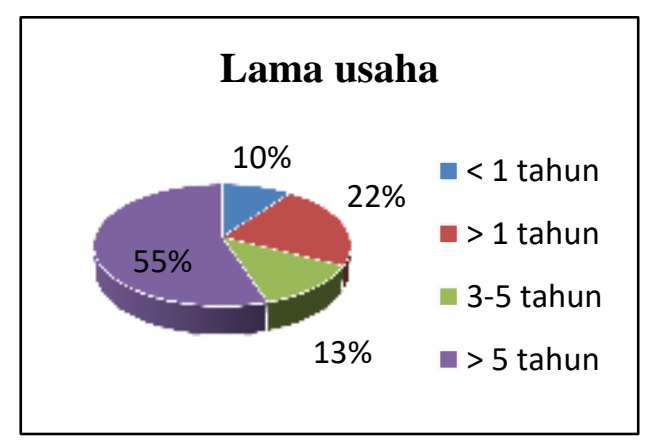

Gambar 3. Lama Usaha
Pada gambar 3. Menunjukkan lama usaha atau umur perusahaan hal ini merupakan karakteristik yang sangat berpengaruh terhadap pertumbuhan perusahaan, berdasarkan gambar 3 tersebut bahwa umur usaha dari UMKM dalam penelitian ini sebagian besar lebih dari 5 tahun yaitu 55\% (44 responden) sedangkan sisanya 1 sampai kurang dari 5 tahun. Umur perusahaan menentukan pengalaman perusahaan dalam beroperasi atas usaha yang dilakukan sehingga kebutuhan akan penerapan tata kelola korporat juga semakin meningkat seiring dengan meningkatnya kompleksitas perusahaan. Semakin lama usaha itu berdiri seharusnya perusahaan cenderung menerapkan tata kelola korporat dalam usahanya. Hal ini dapat dilihat dari tata cara manajer mengelola perusahaannya.

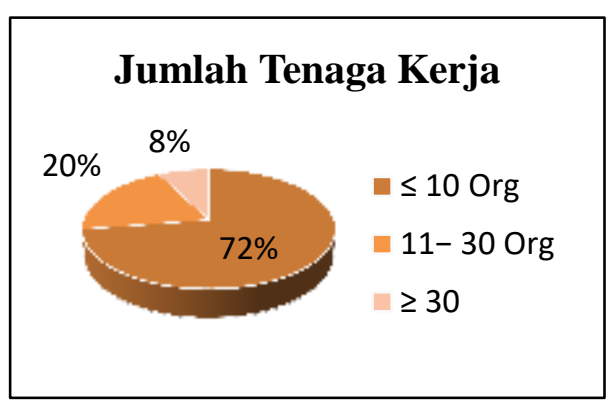

\section{Gambar 4. Jumlah Tenaga Kerja}

Pada gambar 4, menunjukkan bahwa jumlah tenaga kerja pada penelitian ini rata-rata satu usaha memiliki jumlah tenaga kerja kurang dari 10 orang, yaitu sebesar $72 \%$ (58 responden). Berdasarkan hal tersebut dapat diketahui bahwa pengusaha kecil akan mengatur berapa jumlah tenaga kerja pada usahanya untuk memaksimalkan laba.

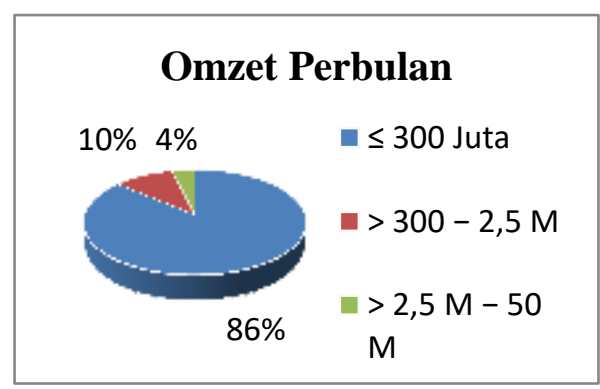

Gambar 5. Omzet

Pada gambar 5, menunjukkan omzet perbulan yang dicapai oleh usaha UMKM dalam sebulan, sebagian besar UMKM memiliki omset usaha $\leq 300$ Juta yaitu sebesar 86\% (69 responden) omset penjualan merupakan jumlah pendapatan atau penjualan yang dihasilkan perusahaan dapat 
menunjukkan perputaran aset atau modal yang dimiliki oleh perusahaan

Berdasarkan gambar 5 omzet penjualan yang dicapai rata-rata perbulan dapat diketahui bahwa pada subjek penelitian ini $86 \%$ jenis usaha mikro dengan omset maksimum 300 juta, sebesar $4 \%$ tergolong dalam jenis usaha kecil dengan omset perbulan rata-rata 300 juta sampai dengan 2,5 milyar sedangkan sebsesar $10 \%$ tergolong jenis usaha menengah dengan omset perbulan rata-rata 2.5 milyar sampai dengan 50 milyar. Jika dilihat pada nilai aset seperti pada gambar 6 menunjukkan bahwa $55 \%$ jenis usaha mikro dengan nilai aset maksimum 50 juta, dan 37\% tergolong jenis usaha kecil dengan nilai aset lebih besar dari 50 juta sampai dengan 500 juta. Sedangkan sisanya $8 \%$ tergolong dalam usaha menengah dengan nilai aset lebih besar dari 500 juta sampai dengan 10 milyar. Hal ini mangindikasikan bahwa nilai aset dari usaha UMKM sebanding dengan omset yang dicapai.

Peran Pemangku kepentingan Pada Penerapan Tata kelola pada UMKM

Penilaian yang Berkaitan dengan Penerapan Tata Kelola Korprat pada UMKM

Tabel.4 Persepsi Responden terhadap Transparansi Tata Kelola Korporat

\begin{tabular}{|l|c|}
\hline \multicolumn{1}{|c|}{ Pilar 1. Transparansi } & $\begin{array}{c}\text { Persetujuan } \\
(\%)\end{array}$ \\
\hline $\begin{array}{l}\text { Mempengaruhi penetapan ke- } \\
\text { bijakan dan aturan organisasi } \\
\text { UMKM }\end{array}$ & 18.75 \\
\hline $\begin{array}{l}\text { Terlibat dalam pengambilan kepu- } \\
\text { tusan strategis, misalnya pencip- } \\
\text { taan produk/jasa baru, segala } \\
\text { kemungkinan dampak risikonya. }\end{array}$ & 20.00 \\
\hline $\begin{array}{l}\text { Memiliki tanggung jawab untuk } \\
\text { menjamin tersedianya informasi } \\
\text { keuangan dan non keuangan un- } \\
\text { tuk pemilik usaha dan pihak ek- } \\
\text { sternal organisasi UMKM. }\end{array}$ & \\
\hline
\end{tabular}

Berdasarkan hasil persepsi responden yang disajikan pada tabel 4 bahwa prinsip transparansi, perusahaan harus menyediakan informasi yang material dan relevan dengan cara yang mudah diakses dan dipahami oleh pemangku kepentingan (KNKG, 2006)

Pada prinsip tranparansi pada subyek penelitian dibagi menjadi 2 poin yaitu:

1. Penetapan kebijakan dan aturan organisasi

2. Pengambil keputusan strategis
Pada poin pertama yaitu kebijakan dan aturan organisasi serta keterbukaan informasi berdasarkan hasil persepsi responden penerapan tata kelola korporat tidak terwujud yaitu pada penetapan kebijakan dan aturan organisasi UMKM hanya sebesar $18.75 \%$, sedangkan tanggung jawab untuk menjamin tersedianya informasi keuangan dan non keuangan untuk pemilik usaha dan pihak eksternal organisasi UMKM sebesar $37.5 \%$ kurang terwujud. Keterlibatan manajer dalam penetapan kebijakan dan aturan organisasi serta laporan keuangan pada subyek penelitian yang diperoleh dari hasil wawancara dengan narasumber dikarenakan subyek penelitian sebagian besar merupakan usaha milik keluarga maka manajer hanya memberikan laporan keuangan kepada seluruh anggota keluarga. Akan tetapi penerapan transparansi pada usaha UMKM dalam poin keterlibatan manajer dalam penetapan kebijakan dan aturan, serta tanggung jawab menjamin tersedianya informasi keuangan dan non keuangan bagi pihak eksternal tidak terlalu diutamakan.

Pada poin kedua yaitu keterlibatan dalam pengambilan keputusan strategis, misalnya penciptaan produk/jasa baru, segala kemungkinan dampak risikonya berdasarkan hasil jawaban responden sebesar $20 \%$ hasil tersebut dapat dikatakan penerapan tata kelola tidak terwujud, dimana seluruh keputusan operasional perusahaan berada pada pemilik perusahaan .

\section{Tabel 5. Persepsi Responden terhadap Akunta- bilitas Tata Kelola Korporat}

\begin{tabular}{|l|c|}
\hline \multicolumn{1}{|c|}{ Pilar 2 AKUNTABILITAS } & $\begin{array}{c}\text { Persetujuan } \\
\text { (\%) }\end{array}$ \\
\hline $\begin{array}{l}\text { Aturan/kebijakan yang ditetap- } \\
\text { kan oleh Pemilik Usaha, misalnya } \\
\text { Anggaran Dasar UMKM. }\end{array}$ & 16.25 \\
\hline $\begin{array}{l}\text { Memiliki tanggungjawab dalam } \\
\text { menyusun dan menyajikan } \\
\text { laporan keuangan organisasi } \\
\text { UMKM. }\end{array}$ & 11.25 \\
\hline $\begin{array}{l}\text { Memiliki tanggungjawab dalam } \\
\text { menyusun laporan kegiatan or- } \\
\text { ganisasi UMKM. }\end{array}$ & 52.5 \\
\hline $\begin{array}{l}\text { Memiliki kewenangan untuk } \\
\text { memonitor dan mengevaluasi } \\
\text { pekerjaan karyawan dibawah } \\
\text { koordinasi saudara. }\end{array}$ & 56.25 \\
\hline
\end{tabular}

Berdasarkan akuntabilitas bahwa UMKM harus dapat mempertanggungjawabkan kinerja secara transparan dan wajar, untuk itu usaha 
UMKM harus dikelola secara benar, terukur dan sesuai kepentingan perusahaan dengan tetap memperhitungkan pemangku kepentingan lain. Pada prinsip akuntabilitas pada penelitian ini dibagi menjadi 2 poin yaitu:

1. Kejelasan aturan /kebijakan perusahaan

2. Kejelasan ukuran kinerja

Dalam kegiatan organisasinya usaha UMKM dalam peneltian ini selalu memberikan tugas dan tanggung jawab kepada masing-masing unit dalam organisasi secara jelas dan terarah sesuai dengan kemampuan-masing-masing.

Berdasarkan tabel 5 tentang Persepsi responden terhadap akuntabilitas tata kelola korporat mengindikasikan bahwa secara operasional subjek penelitian belum semua usaha UMKM memiliki aturan perusahaan dan masih bersifat informal hal ini dapat diketahui dari hasil persepsi tentang Aturan/kebijakan yang ditetapkan oleh Pemilik Usaha, misalnya Anggaran Dasar UMKM sebesar $16.25 \%$ dan tanggungjawab dalam menyusun dan menyajikan laporan keuangan organisasi UMKM sebesar $11.25 \%$.dari hasil tersebut menunjukkan bahwa dari poin kejelasan aturan/ kebijakan perusahaan dalam penerapan tata kelola korporat tidak terwujud.

Pada point kedua dan ketiga berdasarkan tabel 5 tentang tanggungjawab dalam menyusun laporan kegiatan organisasi UMKM serta kewenangan untuk memonitor dan mengevaluasi pekerjaan karyawan menunjukkan hasil masing-masing sebesar $52.5 \%$ dan $56.25 \%$. Hal ini mengindikasikan bahwa usaha UMKM dalam subjek penelitian cukup terwujud baik dalam hal kejelasan ukuran kinerja yang harus dipertangung jawabkan oleh pemangku kepentingan dalam hal tanggungjawab menyusun laporan kegiatan operasional serta monitoring dan evaluasi karyawan yang dipergunakan sebagai landasan untuk pemberian reward dan punishment bagi karyawan.

Tabel 6 Persepsi Responden terhadap Responsibilitas Tata Kelola Korporat

\begin{tabular}{|l|c|}
\hline \multicolumn{1}{|c|}{ Pilar 3 RESPONSIBILITAS } & $\begin{array}{c}\text { Persetujuan } \\
\mathbf{( \% )}\end{array}$ \\
\hline $\begin{array}{l}\text { Memiliki tanggung jawab sosial } \\
\text { organisasi dan melaksanakannya. }\end{array}$ & 13.75 \\
\hline $\begin{array}{l}\text { Menentukan tata tertib dan pe- } \\
\text { doman kerja untuk pelaksanaan } \\
\text { tugas seluruh karyawan organ- } \\
\text { isasi UMKM }\end{array}$ & 32.5 \\
\hline $\begin{array}{l}\text { Terlibat dalam menjelaskan pola } \\
\text { penggajian/pemberian honor }\end{array}$ & 22.5 \\
\hline
\end{tabular}

\begin{tabular}{|ll|l|}
\hline kepada karyawan organisasi & \\
UMKM. & & \\
\hline
\end{tabular}

Responsibilitas perusahan harus mematuhi peraturan perundang-undangan serta melaksanakan tanggungjawab terhadap masyarakat dan lingkungan sehingga dapat terpelihara kesinambungan usaha dalam jangka panjang dan menapat pengakuan sebagai good coorporate citizen. Pada prisip responsibilitas dibagi menjadi 2 poin yaitu:

1. Tanggungjawab perusahaan kepada karyawan

2. Tanggungjawab perusahaan kepada masyarakat

Berdasarkan tabel 6 hasil perhitungan persepsi responden terhadap responsibilitas pada poin 1 yang terdiri pertanyaan yang terkait dengan keterlibatan manajer dalam menentukan tata tertib dan pedoman kerja untuk pelaksanaan tugas seluruh karyawan organisasi perusahaan serta keterlibatan dalam menjelaskan pola penggajian/pemberian honor kepada karyawan organisasi yaitu masing-masing sebesar 32.5\% dan $22.5 \%$ dapat ditarik suatu kesimpulan bahwa penerapan tata kelola yang terkait dengan prinsip responsibilitas pada keterlibatan manajer dalam menentukan tata tertib dan pedoman kerja untuk pelaksanaan tugas seluruh karyawan organisasi perusahaan kurang terwujud, sedangkan yang terkait dengan keterlibatan dalam menjelaskan pola penggajian/ pemberian honor kepada karyawan organisasi tidak terwujud.

Pada poin 2 persepsi responden pada subjek penelitian yang terkait dengan tanggungjawab perusahaan kepada masyarakat diperoleh prosentase $13.75 \%$ sehingga dapat disimpulkan bahwa pada prinsip tersebut tidak terwujud.

Dalam pembahasan independensi, perusahaan harus dikelola secara independen sehingga masing-masing organ perusahaan tidak saling mendominasi dan tidak dapat diitervensi oleh pihak lain.

Pada subjek penelitian usaha UMKM terkadang masih terjadi intervensi dari anggota keluarga. Prinsip independensi menuntut para pemilik usaha agar dapat bertindak secara mandiri sesuai dengan peran dan fungsi yang dimilki.

Berdasarkan tabel 7. diperoleh persentase dari persepsi responden terhadap indpendensi tata kelola korporat yang terkait dengan pemangku kepentingan terhadap kewenangan untuk mengkoordinasikan tugas operasional perusahaan 
diperoleh hasil sebesar $7.5 \%$ sehingga dapat disimpulkan bahwa peran manajer pada subjek penelitian dalam menjalankan kewenangan untuk mengkoordinasikan tugas operasional perusahaan tidak terwujud. Akan tetapi berdasarkan hasil persentase pada pengalaman responden sebagai manajer sebuah organisasi bisnis/umkm memperoleh hasil sebesar $63.75 \%$, dapat disimpulkan bahwa pengalaman manajer dalam bisnis sangat mendukung pengelolaan usaha meskipun mendapat pengaruh dari pihak lain, hal ini dapat dikatakan bahwa prinsip tersebut cukup terwujud.

Tabel 7. Persepsi Responden terhadap Indpendensi Tata Kelola Korporat

\begin{tabular}{|l|c|}
\hline \multicolumn{1}{|c|}{ Pilar 4 INDPENDENSI } & $\begin{array}{c}\text { Persetujuan } \\
\text { (\%) }\end{array}$ \\
\hline $\begin{array}{l}\text { Memiliki kewenangan untuk } \\
\text { mengkoordinasikan } \\
\text { operasional sehari-hari. }\end{array}$ & 7.5 \\
\hline $\begin{array}{l}\text { Memiliki pengalaman sebagai mana- } \\
\text { jer sebuah organisasi bisnis/umkm } \\
\text { sebelum bergabung dengan organ- } \\
\text { isasi UMKM sekarang. }\end{array}$ & 63.75 \\
\hline
\end{tabular}

Tabel 8. Persepsi Responden terhadap Kewajaran Tata Kelola Korporat

\begin{tabular}{|c|c|}
\hline Pilar 5 FAIRNESS/KEWAJARAN & $\begin{array}{c}\text { Persetujuan } \\
(\%)\end{array}$ \\
\hline $\begin{array}{l}\text { Bertanggungjawab terhadap } \\
\text { pengelolaan organisasi UMKM } \\
\text { agar dapat menghasilkan keun- } \\
\text { tungan (profitabilitas) dan memas- } \\
\text { tikan kesinambungan usaha. }\end{array}$ & 10.00 \\
\hline $\begin{array}{l}\text { Memfasilitasi pelaksanaan audit } \\
\text { bila telah diaudit oleh auditor in- } \\
\text { dependen. }\end{array}$ & 73.75 \\
\hline
\end{tabular}

Pada pembahasan mengenai kesetaraan dan kewajaran perusahaan harus memberikan kesempatan kepada pemangku kepentingan untuk memberikan masukan dan menyampaikan pendapat bagi kepentingan perusahaan serta membuka permasalahan terhadap informasi sesuai dengan prinsip transparansi. Berdasarkan tabel 8, diperoleh prosentase pada pemangku kepentingan dalam hal ini manajer bertanggung jawab tehadap pengelolaan organisasi UMKM agar dapat menghasilkan keuntungan dan memastikan kesinambungan usaha sebesar $10 \%$, sehingga dapat disimpulkan bahwa prinsip kesetaraan dan kewajaran pada poin satu tidak terwujud. Mengingat bahwa usaha UMKM pada subjek peneltian lebih banyak pada usaha keluarga sehingga peran manajer banyak diintervensi oleh pemilik sehingga pemangku kepentingan sebagai manajer tidak memiliki kesempatan secara luas untuk melasanakan pengelolaan organisasi UMKM.

Sedangkan prinsip kesetaraan dan kewajaran pada poin kedua yang terkait pemangku kepentingan sebagai manajer dalam memfasilitasi pelaksanan audit bila telah diaudit oleh auditor independen sebesar $73,75 \%$, sehingga dapat disimpulkan bahwa prinsip kewajaran pada poin kedua cukup terwujud.

\section{SIMPULAN}

Berdasarkan hasil analisis dan pembahasan penerapan tata kelola korporat dengan menggunakan 5 prinsip yaitu: Transparansi, Akuntabilitas, Responsibilitas, Independensi dan Fairness/kesetaraan/kewajaran dapat disimpulkan bahwa penerapan prinsip Tranparansi secara keseluruhan dikatakan kurang terwujud, hal ini pada subjek penelitian peran pemangku kepentingan sebagai manajer kurang memiliki peran dalam penetapan kebijakan dan aturan organisasi, pengambilan keputusan strategis. Penerapan prinsip Akuntabilitas terdapat dua poin yang tidak terwujud yang terkait dengan subjek penelitian peran pemangku kepentingan terkait dengan aturan/kebijakan oleh pemilik, tanggung jawab dalam penyusunan dan penyajian laporan keuangan, namun terdapat dua poin cukup terwujud yaitu tanggungjawab menyusun laporan kegiatan organisasi dan kewenangan untuk melaksanakan monitoring dan evaluasi terhadap pekerjaan karyawan. Penerapan prinsip Responsibilitas secara keseluruhan dikatakan tidak terwujud, berdasarkan hasil perhitungan dari 3 poin prinsip tersebut secara rata-rata sebesar 22,92 , hal ini mengindikasikan bahwapemangku kepentingan tidak memiliki peran terhadap pelaksanaan tanggungjawab sosial organisasi dan penentuan tata tertib dan pedoman kerja untuk pelaksanaan serta menjelaskan pola penggajian/reward kepada seluruh karyawan organisasi pada subjek penelitian. Penerapan prinsip independensi, terdapat dua poin yaitu: kewenangan untuk mengkoordinasikan tugas operasional sehari-hari tidak terwujud. Sedangkan poin kedua terkait dengan pengalaman sebagai manajer sebuah organisasi bisnis/umkm cukup terwujud. Penerapan prinsip kesetaraan/kewajaran terdapat dua poin yaitu: terhadap pengelolaan organisasi UMKM agar dapat menghasilkan keuntungan dan memastikan kesinambungan usaha, tidak terwujud. Hal ini 
mengindikasikan bahwa masih terdapat intervensi pengelolaan dari pemilik/keluarga. Sedangkan poin kedua yang terkait memfasilitasi pelaksanaan audit cukup terwujud.

Berdasarkan kesimpulan yang telah dikemukakan diatas, dapat diberikan saran:

Pemilik usaha mikro, kecil dan menengah harusnya melibatkan peran manajer dalam kegiatan operasional perusahaan terutama hal-hal yang bersifat strategis dan penentuan tata aturan organisasi. Pemilik usaha mikro, kecil dan menengah harusnya membuat laopran keuangan tiap tahun sehingga dapat digunakan sebagai acuan untuk pengambilan keputusan ataupun untuk mengajukan tambahan modal. Seharusnya manajer dapat menerapkan tata kelola korporat dalam usahanya agar dapat dikelola dengan lebih baik, karena tata kelola korporat tidak hanya diterapkan pada perusahaan besar saja tetapi dapat diterapkan pada usaha golongan UMKM.

\section{REFERENCES}

Abor, J., dan Adjasi, C. K. (2007). Corporate governance and the small and medium enterprises sector: theory and implications.Corporate governance, Vol 7 No 2, page 111-122

Asian Development Bank, (1999), Asian Development Bank Report 1999, Manila.

Asian Development Bank, (2000), Corporate governance and finance in east Asia: a study of Indonesia, Republic of Korea, Malaysia, Philippine and Thailand. Manila: Asian Development Bank.

Asian Development Bank. (2000a). A consolidated report on corporate governance and financing in east Asia: executive summary. Paper presented at the OECD Second Asian Roundtable on Corporate Governance.

Badan Pengawas Pasar Modal dan Laporan Keuangan, (2011), Potensi Perusahaan UKM untuk Go Publik. Jakarta: Departemen Keuangan Republik Indonesia.

Creswell, J. W. (2009), Research design: qualitative, quantitative, and mixed methods approaches (3rd ed.): Sage Publication, Inc.

Donaldson, L, dan Davis, J. H., (1989), CEO governance and shareholder returns: Agency theory or stewardship theory. Paper dipresentasikan pada the annual meeting of the Academy of Management, Washington, DC.

Donaldson, L. dan Davis, J. H., (1991). Stewardship theory or agency theory: CEO Governance and shareholder returns.Australian, Journal of Management, Vol 16 No 1, page: 49-64
Hamdani, (2016), Good Corporate Governance: Tinjauan Etika dalam Praktek dan Bisnis, Mitra Wacana Media: Jakarta.

Hartono. J., (2005), Metodologi Penelitian Bisnis: Salah Kaprah dan Pengalaman-Pengalaman, Penerbit BPFE, Yogyakarta.

Iu, J., dan Batten, J., (2001). The implementation of OECD corporate governance principles in post-crisis Asia, Journal of Corporate Citizenship, Vol 4, page 47-62.

Jensen, M. C. dan Meckling, W. H., (1976), Theory of The Firm: Managerial Behavior, Agency Cost and Ownership Structure, Journal of Financial Economics, Vol 3, page. 1-77.

Kompas.com, (2017), Potensi Bangkitnya UMKM dan Industri Kreatif melalui "Peer-to-Peer Lending, https://ekonomi.kompas.com/read/2017/04/04/

Komite Nasional Kebijakan Governance., (2006). Pedoman Umum Good Corporate Governance Indonesia, Jakarta.

Koech, P., (2016) Board Characteristic as a Determinant of Effectiveness of Corporate Governance in State Corporation in Kenya. International Journal of Business and Commerce, Vol 5 No 04, page 37-62.

Lane, S., Astrachan, J., Keyt, A. dan McMillan, K. (2006). "Guidelines for Family,Business Boards of Directors." Family Business Review, Vol 19 No 2, page 147-167.

Lembaga Pengembangan Perbankan Indonesia, (2015), Profil Bisnis Usaha Mikro Kecil dan Menengah (UMKM), LPPI dan Bank Indonesia.

Niode, I. Y., (2009), SEKTOR UMKM DI INDONESIA: Profil , Masalah, Dan Strategi Pemberdayaan, Jurnal Kajian Ekonomi dan Bisnis OIKOS-NOMOS, Volume 2, Nomor 1.

Nugraheni, B.,D. dan Martono, C., (2015), Analisis Mekanisme Tata Kelola, Manajemen Laba dan Pengungkapan Informasi Lingkungan Perusahaan pada Industri Manufaktur di Indonesia, Artikel Tidak Dipublikasikan, Perpustakaan Unika Widya Mandala, Surabaya.

Nugraheni, B.,D. dan Martono, C., (2017), Analisis Penerapan Tata Kelola Korporat pada Industri Produk Tekstil Kecil dan Menengah, Artikel Tidak Dipublikasikan Perpustakaan Widya Mandala, Surabaya.

Organisation for Economic Co-operation Development, (2006), Literacy Skills for the World of Tomorrow, http://www.oecd.org/edu/school/2960581.pdf.

Palupijati, S., (2013), Tata Kelola pada UKM: Perbandingan Penerapan Pada Bisnis Keluarga 
dengan Bisnis Non Keluarga, Tesis Universitas Gadjah Mada.

Widarti, P., (2017), Kembangkan UMKM, Pemkot Surabaya Siapkan Rp11 Miliar. Diakses Bisnis.com $06 \quad$ Maret 2017.https://Kalimantan.bisnis.com/

Putri, W.H., dan Bakhtiar, I., (2015), Sistem Tata Kelola Keuangan Industri Kecil dan Pengrajin Kayu sebagai Upaya Penyehatan dan Pelaksanaan Tanggungjawab Sosial Perusahaan dalam Pengentasan Kemiskinan. Seminar Nasional Universitas PGRI Yogyakarta.

Raharjo, E., (2007), Teori Agensi dan Teori Stewardship dalam Perspektif Akuntansi. Fokus Ekonomi, Vol. 2, No. 1.

Roida, H.Y. Sunarjanto, A., dan Jayaprana, W., (2010), Internasionalisasi usaha mikro, kecil, dan menengah (UMKM) ditinjau dari tipe kepemilikan: studi empiris di Jawa Timur, Jurnal Manajemen Teori dan Terapan, Vol 3 No 2.

Tadikapury, V. J., (2011), Penerapan Good Corporate Governance (GCG) pada PT Bank X Tbk Kanwil X, Skripsi Universitas Hasanuddin, Makasar.

Undang-Undang Usaha Mikro, Kecil, dan Menengah Nomor 20 Tahun 2008, (2008), Diperoleh melalui https://www.bi.go.id/id/tentang-bi/uu-151 bi/Documents/UU20Tahun 2008UMKM.pdf diakses pada tanggal 9 Maret 2017

World Bank. (1999).World Bank report. New York: World Bank.

Zhang, X. dan Thiam, M., (2014), Assessing the role of stakeholders in the implementation of SME's Governance Principles in France, International Journal of Business and Commerce, Vol. 3, No 5 . 